\title{
DIFFERENTIATION OF PERIPHYTON AND PHYTOPLANKTON ASSEMBLAGES IN ANTHROPOGENICALLY TRANSFORMED CONDITIONS OF THE LITTORAL ZONE IN A SHALLOW URBAN LAKE (LAKE JEZIORAK MAŁY, POLAND)
}

\author{
ZĘBEK, E. \\ University of Warmia and Mazury, Faculty of Law and Administration, \\ Law of Environmental Protection Laboratory, Warszawska 98, 10-702 Olsztyn, Poland \\ *Corresponding author \\ e-mail: elzbieta.zebek@uwm.edu.pl \\ (Received 21 ${ }^{\text {st }}$ November 2012 ; accepted $2^{\text {nd }}$ September 2013)
}

\begin{abstract}
This study of periphyton (periphyton in separator pipes, epilithon and epiphyton) and phytoplankton (pelagial) assemblage differentiation was conducted in Lake Jeziorak Mały within an anthropogenically transformed littoral zone. Analysis was conducted on the differences in abundance and biomass of these assemblages in relationship to the physico-chemical water parameters, species' similarity, diversity and environmental requirements of these assemblages, from April to October of 1997-2003 and in 2005. The periphyton in the pipes and epilithon were found to be the most similar assemblages. Despite similar substratum characteristics, changes in the physico-chemical water parameters, and especially those in $\mathrm{PO}_{4}, \mathrm{Si}$ and $\mathrm{Cl}$, were found to affect these assemblages' development. This was supported by correlations between the characteristic species and nutrients. While the growth of epiphyton was mainly related to changes in calcium and nitrogen concentration, phytoplankton depended more on conductivity, $\mathrm{pH}$ and $\mathrm{Fe}$. The presence of seven algal groups with different environmental requirements indicated considerable differentiation of the studied assemblages resulting from anthropogenic transformation of this littoral zone. The installation of separators and also stone accumulations in this zone contributed to the creation of new habitats for periphytic algae which utilized the common pool of nutrients. It may therefore have indirectly influenced phytoplankton dominated by cyanobacteria.
\end{abstract}

Keywords: periphyton, phytoplankton, differentiation, eutrophic lake, CCA.

\section{Introduction}

The littoral zones of lakes have wide structural variety with various dynamics of ecological processes and are particularly sensitive to changes in environmental conditions and anthropogenic pressures (Radwan et al., 1998). According to Burchardt (1998), maximal primary productivity in eutrophic water bodies occurs in the littoral zone, which also functions as a biofilter, collecting both water and organisms flowing down from the catchment. The efficiency of nutrient retention depends on the biological diversity of littoral habitats. The differentiation of the littoral zone in time and space, i.e. the number of accessible habitats per surface unit is of great importance for the maintenance of species diversity (Reynolds, 1984). Especially in urban lakes this is a crucial factor, because they are feed by a fast surface run-off whereas in vegetal cover areas interception leads to a slow inflow. Percolation under natural conditions results in a steady but relatively low concentration of nutrients being discharged into receiving waterbodies over time (Guzkowska and Gasse, 1990). The littoral zones of such lakes can be transformed anthropogenically, which results in new habitats being created for animals and plants, including periphytic algae. 
Periphyton is composed of communities of plant and animal organisms overgrowing submerged surfaces such as stones, macrophytes, and artificial substrata (Bohr, 1973; Szlauer, 1996). Plant periphyton includes both large forms of algae such as filamentous and thallus-like chlorophytes and small organisms, including diatoms. Periphyton is both an important primary producer in littoral zones of lakes and a food source for invertebrates. Ecologically, periphyton play an important role in nutrient cycling and biological productivity in aquatic system, linking a number of bottom-up and top-down processes. Because of its sedentary nature, periphyton is a good indicator of quality of waters and ecological functioning in fresh waters (Bohr and Miotk, 1979; Müller, 2000; Dodds, 2003; Azim et al., 2005).

Particular periphytic algae have specific environmental and physico-chemical requirements. According to Pełechaty and Burchardt (1998), a particular state of the natural environment or intensity of environmental factors provide conditions for the occurrence of a given species, characterized by a specified range of tolerance to factors including water temperature and nutrient concentration. Periphyton assemblages composed of many populations can be limited simultaneously not only by nutrient insufficiency, but also different species can be limited by nutrient type. Differing responses of species to different temperatures and current environments certainly affect our prediction of periphyton growth as a function of nutrients. Not only do different diatoms respond to nutrients differently, but also filamentous algae add complexity by responding to nutrients independently and forming an additional substratum for algal colonization (Rier and Stevenson, 2006).

In lakes, periphyton inhabiting artificial substrata submerged in the pelagial can be potentially used for removal of phosphorus from the water (Jöbgen et al., 2004). This involves a certain type of bio-manipulation. In the littoral zone of the lake, periphyton may be able to compete with phytoplankton for nutrients, and may indirectly reduce the phytoplankton biomass or bloom frequency via nutrient removal from the water column (Hansson, 1990; Danilov and Ekuland, 2001; Rodusky at al., 2001).

The urban lake of Jeziorak Mały is an example of a eutrophic water body, where the littoral zone was anthropogenically transformed by the installation of separators, and also by the accumulation of stones. The objective of this paper is to determine the effects of the anthropogenic transformation of the littoral zone on the differentiation of periphyton and phytoplankton assemblages in our study conducted in this lake in 1997 2003 and 2005. The formulated hypothesis states that this anthropogenic transformation of the littoral zone by the installation of separators and stone accumulation affects the differentiation of periphyton and phytoplankton assemblages in this lake. Answers to the following questions were sought to verify this hypothesis:

(1) Do quantitative and qualitative seasonal differences occur in the periphyton and phytoplankton assemblages due to environmental conditions?

(2) Do relationships exist between the periphyton assemblages and phytoplankton?

(3) Do differences exist in the environmental requirements of the periphyton and phytoplankton assemblages? 


\section{Materials and methods}

\section{Study area}

Jeziorak Mały is a shallow urban lake with a mean depth of $3.4 \mathrm{~m}$ and covering 26 ha in the Mazurian Lakeland in north-eastern Poland (Fig. 1). The lake can be recognized as a model lake. It is a eutrophic lake located in this moderate zone with typical basin shape, shallow, and isolated from other water-bodies. The lake is connected to Lake Jeziorak Duży by a narrow canal $4 \mathrm{~m}$ wide and $4 \mathrm{~m}$ deep. Due to the high disproportion between the surface areas of the lakes (26 ha and 3219 ha, respectively), this connection constitutes a concrete barrier used for water levelling. It is not a factor determining the mixing of these lakes' waters.

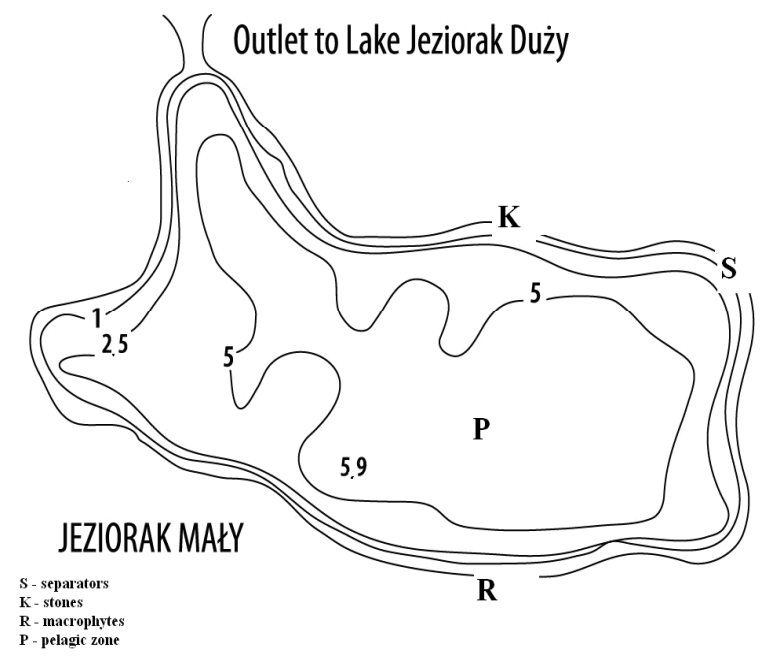

Figure 1. Morphometric map of Lake Jeziorak Maty

For many decades, this lake received untreated municipal sewage from the town of Ilawa. Since 1991, however, effluent has been treated at a local waste-water treatment plant. The activities to improve the lake's water quality began in 1997, and they have been ongoing since that time. These included the installation of separators for the pretreatment of storm water influent, and a fountain-based water aeration system. The lake constitutes an outlet for the storm sewer system, which is common in smaller cities. In 1996 in the lake's littoral zone, construction commenced on the Unicon System lamella separators, and these began operating in the spring of 1997. Before then, these pipes carried untreated storm waters directly into the lake. Their function is to separate petroleum compounds and silt and sand from waters flowing in the separated rainwater sewerage system. The efficiency of the separation of petroleum derivative substances reached $97 \%$, at a nominal discharge of $160 \mathrm{l} \mathrm{s}^{-1}$. The maximum separator discharge was $1,600 \mathrm{l} \mathrm{s}^{-1}$, in which only $10 \%$ these substances were treated. Storm water pretreatment occurs in the catchment of Lake Jeziorak Mały which has a total area of 70 ha (PUH EKOL, 1995). The lake shores were partly covered with concrete or reinforced with fascine, and most of the bottom was composed of stones and gravel. Lake Jeziorak Mały is therefore an example of a lake with a reversed coastal zone management system 
comprising approximately 30\% macrophytes and 70\% concrete bank. Phyto-littoral species there include macrophytes; mainly Phragmites communis, Scirpus lacustris (L.) Palla, Acorus calamus L., and Glyceria aquatica (L.) Wahlb., while the bottom was muddy and covered with decomposing plant debris.

\section{Sampling}

Periphyton samples were collected monthly from April to October in the years 19972003 and 2005 on the three substrates located in the littoral zone, together with phytoplankton from the pelagic zone of lake Jeziorak Mały; as follows:

1) periphyton from the pipes of separators which drain storm waters (S);

2) epilithon from the surfaces of stones accumulated in $1997(\mathrm{~K})$;

3) epiphyton from the leaves of Acorus calamus L. plants ( R);

4) phytoplankton from the $1 \mathrm{~m}$ euphotic zone in the pelagial, where the mean water transparency in 1997-2003 and 2005 registered $0.80 \mathrm{~m} \mathrm{(P)}$.

The periphyton was scraped from the pipes, from $1 \mathrm{~cm}^{2}$ stones and from macrophyte leaves which had previously been cut into $5 \mathrm{~cm}$ lengths. The pipes and stones were often found to be overgrown with Cladophora glomerata (L.) Kützing filamentous green algae formed a natural substratum for periphytic algae. The periphyton was shaken carefully in distilled water to separate algae from chlorophyte thalli, and the residue was scraped from the macrophyte leaves with a knife. The samples were rinsed and preserved using an ethanol and formaldehyde solution. The phytoplankton samples were collected with a Ton 5-liter plankton sampler from the surface layer of the pelagic zone. These samples were poured through a $30 \mu \mathrm{m}$ mesh plankton net, and then preserved with Lugol's solution and a 4\% formaldehyde solution. A total of 124 samples were collected. The basic physical and chemical water parameters were measured directly at the sampling sites. Here, the water temperature values and oxygen content (using a HI 9143 oxygen meter), and $\mathrm{pH}$ and conductivity (using a CONMET 1 conductometer) were obtained in situ. The concentration of nutrients (orthophosphates, silicon, calcium, total nitrogen and chlorides) was measured in the laboratory using a NOVA 400 spectrophotometer.

\section{Analysis}

Plant periphyton and phytoplankton were analyzed in this study. The terms periphyton and phytoplankton concern all prokaryotic (cyanobacteria) and eukaryotic organisms, from which diatoms, chlorophytes, dinoflagellates, chrysophytes, and cryptophytes were analyzed. Qualitative and quantitative determinations of planktonic and periphytic algae were performed with an Alphaphot YS2 optical microscope at magnifications of 10x, 20x, 40x and 100x. Diatom preparations followed the standard procedures described by Battarbee (1979). Algae biomass was calculated for biovolume by comparing the algae with their geometric shapes (Rott, 1981). The mean biomass was calculated for 10 individuals of each planktonic and periphytic algae species. In order to level-out differences in organism densities in the periphyton and phytoplankton, their numbers in each sample were determined in a planktonic chamber with a capacity of $1 \mathrm{ml}$ in 5000 fields of vision with 20x magnification. The abundance and biomass of periphyton and phytoplankton was expressed in the identical basic volume unit of $1 \mathrm{ml}$. The frequencies of occurrence of organisms in the assemblages were approximately equal throughout the fields of vision for the total 155 taxa identified 
in all samples. This was supported by the analysis of significance of differences between frequencies of occurrence of the studied assemblages (STATISTICA version 8 ). The conducted analysis demonstrated no statistically significant differences between these algal assemblages at $\mathrm{p}>0.05$ (Table 1).

Table 1. Coefficients common for the periphyton and phytoplankton assemblages in 5000 fields of vision in Lake Maty during 1997-2003 and 2005 (Zębek 2012)

\begin{tabular}{|c|c|c|c|c|}
\hline Variable & $\begin{array}{l}\text { Periphyton in } \\
\text { the separator } \\
\text { pipes }(S)\end{array}$ & $\begin{array}{l}\text { Epilithon } \\
\text { (K) }\end{array}$ & $\begin{array}{l}\text { Epiphyton } \\
\text { (R) }\end{array}$ & $\begin{array}{c}\text { Phytoplankton } \\
\text { (P) }\end{array}$ \\
\hline $\begin{array}{l}\text { Mean occurrence frequency } \\
\text { at } 155 \text { taxa }\end{array}$ & 5.30 & 5.19 & 5.47 & 5.10 \\
\hline Standard deviation & 6.63 & 7.22 & 7.24 & 6.72 \\
\hline Level of significance of & $0.45(\mathrm{~K})$ & $0.37(\mathrm{R})$ & $0.32(\mathrm{P})$ & \\
\hline differences between algal & $0.42(\mathrm{R})$ & $0.45(\mathrm{P})$ & & \\
\hline assemblages & $0.40(\mathrm{P})$ & & & \\
\hline $\begin{array}{l}\text { Level of significance for all } \\
\text { studied assemblages }\end{array}$ & & 0.83 & & \\
\hline $\begin{array}{l}\text { Coefficients of taxa } \\
\text { occurrence frequency }\left(\mathrm{p}^{\wedge}\right)\end{array}$ & 31.62 & 30.96 & 32.62 & 30.42 \\
\hline
\end{tabular}

All data was analyzed statistically using STATISTICA 8.0 and Canoco for Windows 4.5. Analysis of variance was performed to the threshold level of $p<0.05$ significant difference between the periphyton (periphyton in separator pipes, epilithon and epiphyton) and the phytoplankton (pelagial) assemblages in the spring, summer and autumn seasons. One-way ANOVA's with the Tukey test for uneven N was used to assess the significance of differences in periphyton and phytoplankton assemblages in these three seasons. Data clustering by the Euclidean distance method was used to determine the differences in the species composition of periphyton and phytoplankton assemblages. The periphyton and phytoplankton species' diversity was analyzed to calculate the Shannon-Weaver index (1949). A canonical correspondence analysis (CCA) was performed to relate water chemistry variables to the periphyton and phytoplankton species' assemblages occurring in the April to October period. These relationships were also presented on the tri-plot graph by Canoco for Windows 4.5 software, and they were further confirmed by calculating Spearman's rank correlation coefficient by STATISTICA version 8. Non-parametric methods were used because this data is not normally distributed. On the basis of this conducted correlation analysis, the species characteristics of periphyton and phytoplankton assemblages were divided into seven groups in terms of environmental requirements.

\section{Results}

\section{Seasonal differentiation in periphyton and phytoplankton assemblages}

The mean abundance of periphyton in Lake Jeziorak Mały ranged from 39,821 ind. $\mathrm{ml}^{-1}$ for epiphyton to 70,535 ind. $\mathrm{ml}^{-1}$ for periphyton in the pipes, while the abundance of phytoplankton in the pelagial recorded 31,272 ind. $\mathrm{ml}^{-1}$. However, the mean biomass of periphyton was recorded from $0.067 \mathrm{mg} \mathrm{ml}^{-1}$ for epiphyton to $0.226 \mathrm{mg} \mathrm{ml}^{-1}$ for 
epilithon and $0.065 \mathrm{mg} \mathrm{ml}^{-1}$ for phytoplankton. The highest mean orthophosphate concentration was found to be $0.56 \mathrm{mg} \mathrm{PO}_{4} \mathrm{l}^{-1}$ on the sites with stones, and the lowest was $0.24 \mathrm{mg} \mathrm{PO}_{4} \mathrm{l}^{-1}$ on the sites with macrophytes. Standard deviations did not exceed the triple value of arithmetic means, thus indicating that the data was statistically representative (Table 2).

Table 2. Means $(M)$ and standard deviations $(S D)$ of periphyton assemblages ( $S-$ periphyton in separator pipes, $K$ - epilithon, $R$ - epiphtyton) and phytoplankton ( $P$ pelagial) and orthophosphate concentrations at these sites in Lake Jeziorak Maty in the years 1997-2003 and 2005

\begin{tabular}{|c|c|c|c|c|c|c|c|c|}
\hline & \multicolumn{2}{|c|}{$S(N=54)$} & \multicolumn{2}{|c|}{$K(N=51)$} & \multicolumn{2}{|c|}{$R(N=49)$} & \multicolumn{2}{|c|}{$P(N=30)$} \\
\hline & $\mathbf{M}$ & SD & $\mathbf{M}$ & SD & $\mathbf{M}$ & SD & $\mathbf{M}$ & SD \\
\hline $\begin{array}{l}\text { Abundance } \\
\text { (ind. } \mathrm{ml}^{-1} \text { ) }\end{array}$ & 70353 & 72115 & 65173 & 54576 & 39821 & 42127 & 31272 & 33623 \\
\hline $\begin{array}{l}\text { Biomass } \\
\left(\mathrm{mg} \mathrm{ml}^{-1}\right)\end{array}$ & 0.175 & 0.265 & 0.226 & 0.295 & 0.067 & 0.158 & 0.065 & 0.117 \\
\hline $\begin{array}{l}\text { Orthophosphates } \\
\left(\mathrm{mg} \mathrm{PO}_{4} \mathrm{l}^{-1}\right)\end{array}$ & 0.41 & 0.36 & 0.56 & 0.60 & 0.24 & 0.25 & 0.32 & 0.98 \\
\hline
\end{tabular}

In this study, differences in abundance and biomass of periphyton and phytoplankton assemblages were also recorded in the Spring, Summer and Autumn seasons. Despite algal abundance in spring, the differences between abundance and biomass of the studied assemblages in these seasons were highly statistically significant (Table 3).

Table 3. Level of significance ( $p<0.05$; ANOVA variation analysis ) of periphyton and phytoplankton assemblages in the seasons in Lake Jeziorak Maty in the years 1997-2003 and 2005

\begin{tabular}{c|c|c|c}
\hline & Spring (April, May) & $\begin{array}{c}\text { Summer (June, July, } \\
\text { August) }\end{array}$ & $\begin{array}{c}\text { Autumn (September, } \\
\text { October) }\end{array}$ \\
\hline Abundance & 0.073382 & $0.000136^{*}$ & $0.000718^{*}$ \\
Biomass & $0.004371^{*}$ & $0.001135^{*}$ & $0.022680^{*}$ \\
\hline
\end{tabular}

Although seasonal statistically significant differences were not demonstrated in abundance and biomass within the individual periphyton and phytoplankton assemblages, statistically significant differences were recorded between these assemblages for the seasons. The ANOVA shows that significant differences were recorded for the following factors; (1) in the abundance between periphyton in separator pipes and epiphyton and phytoplankton in summer (Fig. 3A), and between epiphyton, phytoplankton and periphyton in the separator pipes and epilithon in autumn (Fig. 4A); (2) in the biomass between epilithon and epiphyton and phytoplankton in spring and autumn (Fig. 2, 4B) and between epiphyton and periphyton in the separator pipes and epilithon in summer (Fig. 3B). In these periods, the following mean nutrient concentrations were recorded at the sites; (1) orthophosphates from $0.15 \mathrm{mg} \mathrm{PO}_{4} \mathrm{l}^{-1}$ in autumn to $0.99 \mathrm{mg} \mathrm{PO}_{4} \mathrm{l}^{-1}$ in spring; (2) calcium from $65 \mathrm{mg} \mathrm{Ca}^{-1}$ in autumn to $160 \mathrm{mg}$ $\mathrm{Ca}^{-1}$ in spring; (3) silicon from $0.51 \mathrm{mg} \mathrm{Si}^{-1}$ in summer to $3.12 \mathrm{mg} \mathrm{Si}^{-1}$ in autumn, and (4) total nitrogen from 1.6 to $3.7 \mathrm{mg} \mathrm{N}^{-1}$ in autumn. However, no significant 
differences were found between the periphyton in the separator pipes and epilithon in summer and autumn, at the approximate orthophosphate levels of 0.34 and $0.31 \mathrm{mg} \mathrm{PO}_{4}$ $1^{-1}$, respectively (Table 4).

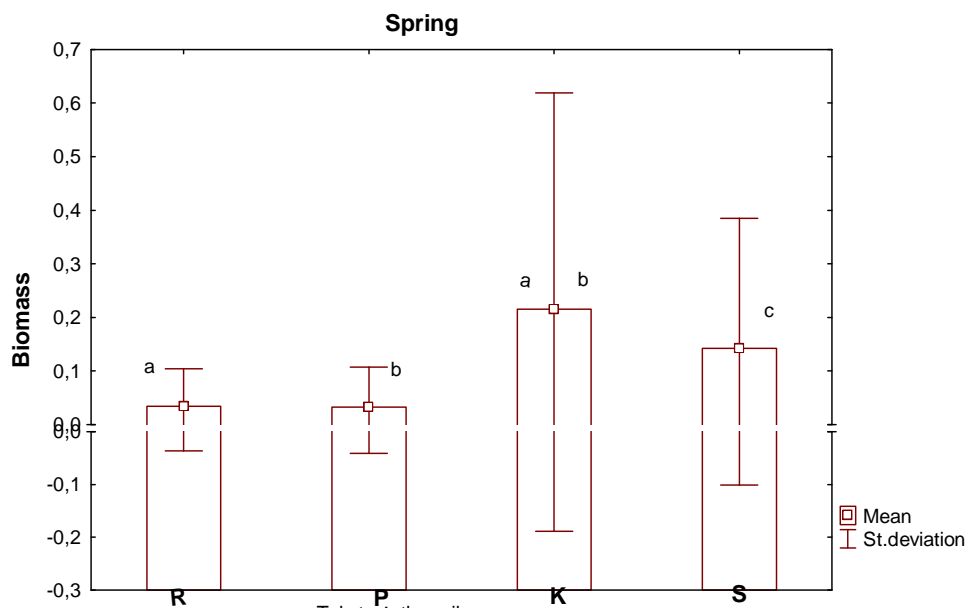

Figure 2. Differentiation of biomass of periphyton assemblages ( $S$ - periphyton in separator pipes, $K$-epilithon, $R$ - epiphtyton) and phytoplankton ( $P$ - pelagial) in spring (Tukey test, ANOVA) in Lake Jeziorak Maty in the years 1997-2003 and 2005
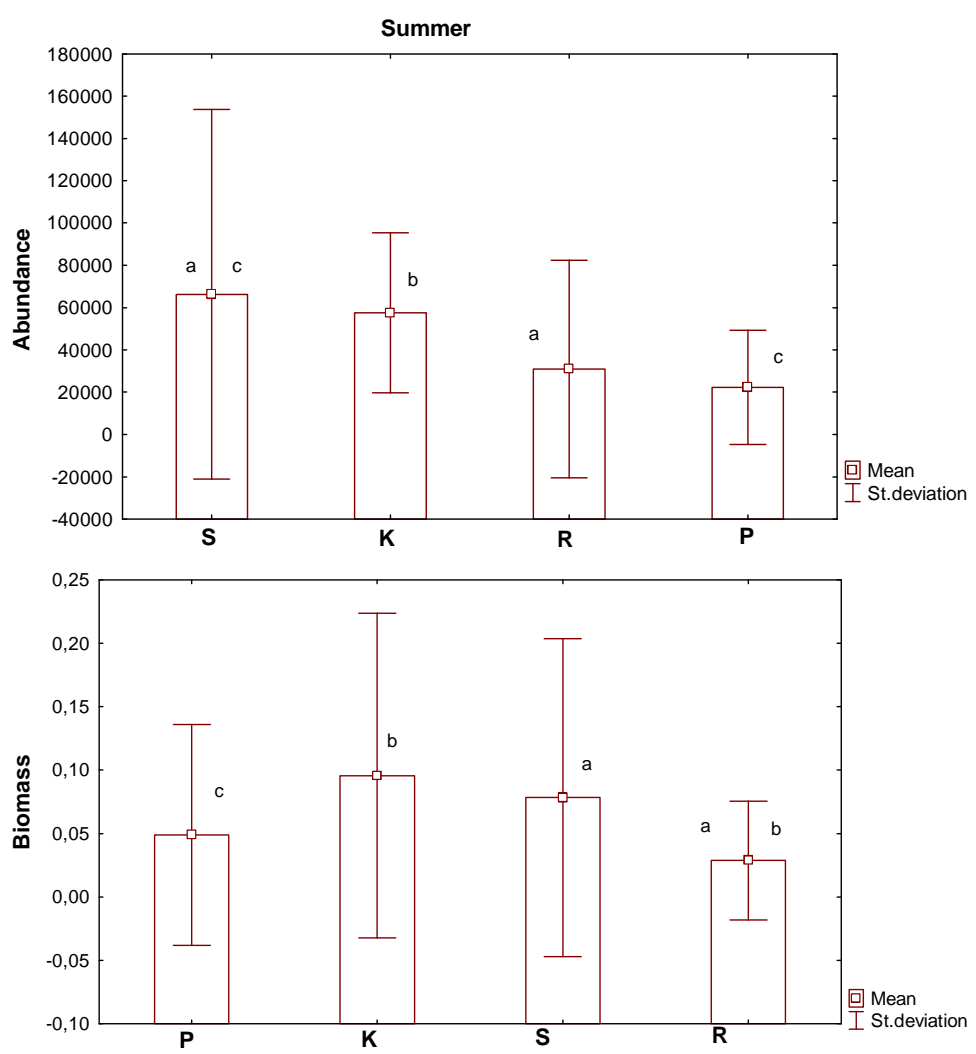

Figure 3. Differentiation of abundance $(A)$ and biomass $(B)$ of periphyton assemblages $(S-$ periphyton in separator pipes, $K$ - epilithon, $R$ - epiphtyton) and phytoplankton ( $P$ - pelagial) in summer (Tukey test, ANOVA) in Lake Jeziorak Maty in the years 1997-2003 and 2005 

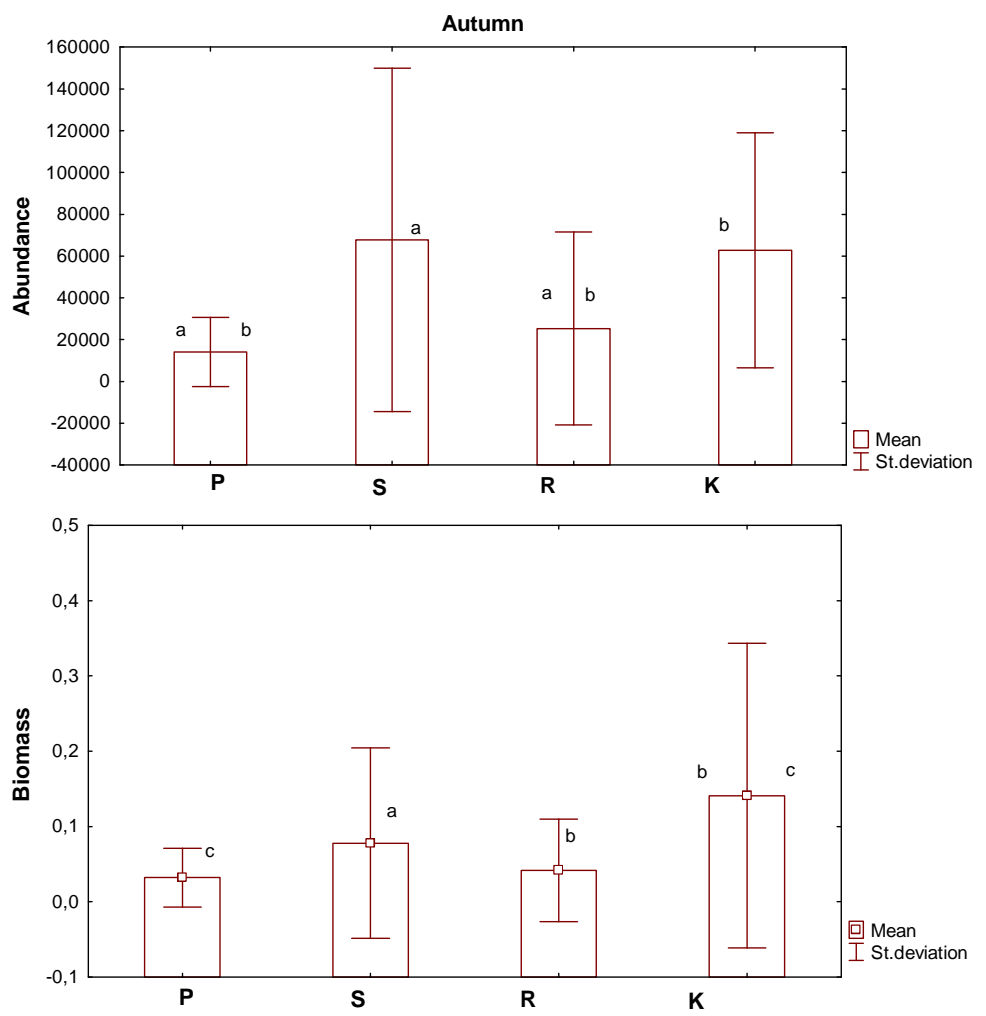

Figure 4. Differentiation of abundance $(A)$ and biomass $(B)$ of periphyton assemblages $(S-$ periphyton in separator pipes, $K$ - epilithon, $R$ - epiphtyton) and phytoplankton ( $P$ - pelagial) in autumn (Tukey test, ANOVA) in Lake Jeziorak Maty in the years 1997-2003 and 2005

Table 4. Nutrient concentrations (mean $\square \pm$ standard deviation) at the studied sites (Sseparators, $K$ - sites with stones, $R$ - sites with macrophytes, $P$ - pelagial) in the seasons in Lake Jeziorak Maty in 997-2003 and 2005

\begin{tabular}{|c|c|c|c|c|}
\hline \multirow[t]{2}{*}{ Nutrient } & \multicolumn{4}{|c|}{ Spring (April and May) } \\
\hline & $\mathbf{S}$ & $\mathbf{K}$ & $\mathbf{R}$ & $\mathbf{P}$ \\
\hline Orthophosphates $\left(\mathrm{mg} \mathrm{PO}_{4} \mathrm{l}^{-1}\right)$ & $0.45 \pm 0.42$ & $0.45 \pm 0.48$ & $0.27 \pm 0.34$ & $0.99 \pm 2.32$ \\
\hline Calcium $\left(\mathrm{mg} \mathrm{Ca} \mathrm{l}^{-1}\right)$ & $120 \pm 90$ & $106 \pm 73$ & $89 \pm 77$ & $80 \pm 72$ \\
\hline Silicon $\left(\mathrm{mg} \mathrm{Si}^{-1}\right)$ & $0.85 \pm 1.10$ & $0.74 \pm 0.96$ & $0.78 \pm 0.92$ & $0.70 \pm 0.85$ \\
\hline \multirow[t]{3}{*}{ Total nitrogen $\left(\mathrm{mg} \mathrm{N}^{-1}\right)$} & $4.3 \pm 3.5$ & $2.7 \pm 1.6$ & $2.5 \pm 1.3$ & $0.5 \pm 0.8$ \\
\hline & \multicolumn{4}{|c|}{ Summer (June, July, August) } \\
\hline & $\mathbf{S}$ & $\mathbf{K}$ & $\mathbf{R}$ & $\mathbf{P}$ \\
\hline Orthophosphates $\left(\mathrm{mg} \mathrm{PO}_{4} \mathrm{l}^{-1}\right)$ & $0.34 \pm 0.40$ & $0.31 \pm 0.32$ & $0.18 \pm 0.19$ & $0.13 \pm 0.15$ \\
\hline Calcium $\left(\mathrm{mg} \mathrm{Ca} \mathrm{l}^{-1}\right)$ & $128 \pm 124$ & $91 \pm 58$ & $68 \pm 46$ & $89 \pm 58$ \\
\hline Silicon (mg Si l $\left.{ }^{-1}\right)$ & $1.07 \pm 0.94$ & $0.64 \pm 0.22$ & $0.51 \pm 0.22$ & $1.82 \pm 3.04$ \\
\hline \multirow[t]{3}{*}{ Total nitrogen $\left(\mathrm{mg} \mathrm{N}^{-1}\right)$} & $3.6 \pm 2.7$ & $2.3 \pm 1.4$ & $1.7 \pm 0.8$ & $2.2 \pm 1.3$ \\
\hline & \multicolumn{4}{|c|}{ Autumn (September and October) } \\
\hline & $\mathbf{S}$ & $\mathbf{K}$ & $\mathbf{R}$ & $\mathbf{P}$ \\
\hline Orthophosphates $\left(\mathrm{mg} \mathrm{PO}_{4} \mathrm{l}^{-1}\right)$ & $0.47 \pm 0.31$ & $0.98 \pm 0.79$ & $0.30 \pm 0.23$ & $0.15 \pm 0.13$ \\
\hline Calcium $\left(\mathrm{mg} \mathrm{Ca} \mathrm{l}^{-1}\right)$ & $160 \pm 122$ & $117 \pm 58$ & $145 \pm 65$ & $65 \pm 38$ \\
\hline Silicon $\left(\mathrm{mg} \mathrm{Si} \mathrm{l}^{-1}\right)$ & $2.76 \pm 3.25$ & $1.01 \pm 0.40$ & $0.89 \pm 0.40$ & $3.12 \pm 1.40$ \\
\hline Total nitrogen $\left(\mathrm{mg} \mathrm{N}^{-1}\right)$ & $2.6 \pm 1.3$ & $3.7 \pm 0.5$ & $2.8 \pm 1.4$ & $1.6 \pm 1.1$ \\
\hline
\end{tabular}




\section{Species analysis of periphyton and phytoplankton assemblages}

In this study, species similarity and diversity enabled the comparison of features of the studied periphyton and phytoplankton assemblages. The Euclidean diagram showed that the greatest species composition similarity consists of the smallest distance between the periphyton in separator pipes and epilithon, and the least similarity was between the periphyton in separator pipes and phytoplankton (Fig. 5). The highest Shannon-Weaver species diversity index was recorded for epiphyton at 4.7346 bit ind. $^{-1}$ at the taxa number of 130, and the lowest diversity index was for phytoplankton $\left(2.9962 \mathrm{bit}_{\text {ind. }}^{-1}\right)$ at 125 taxa (Fig. 6).

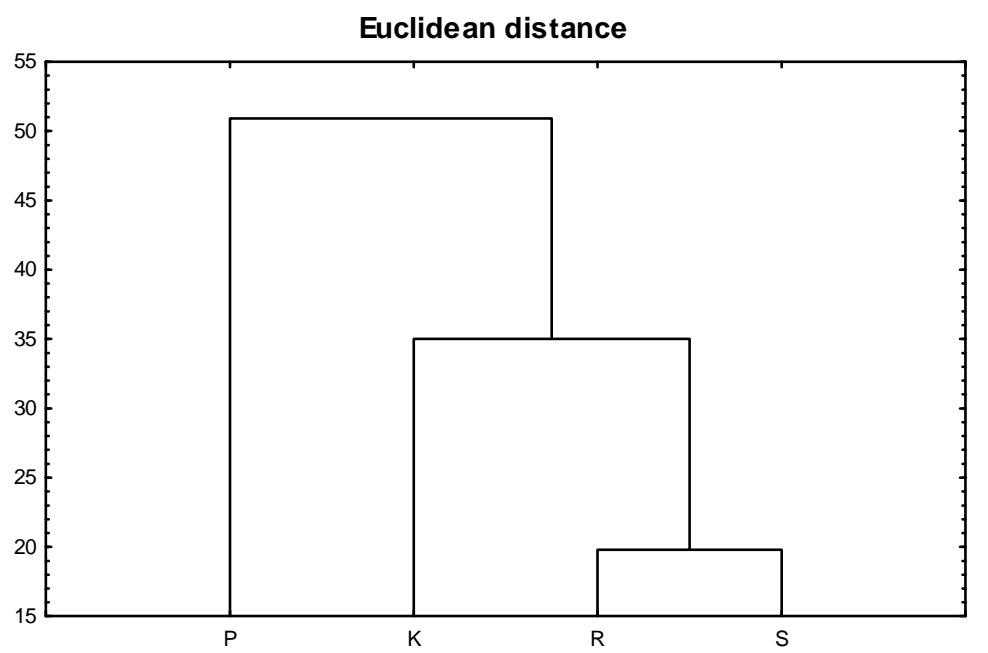

Figure 5. Dendrogram of Euclidean distances between periphyton assemblages ( $S$ - periphyton in separator pipes, $K$ - epilithon, $R$ - epiphtyton) and phytoplankton $(P-$ pelagial $)$ in Lake Jeziorak Maty in the years 1997-2003 and 2005

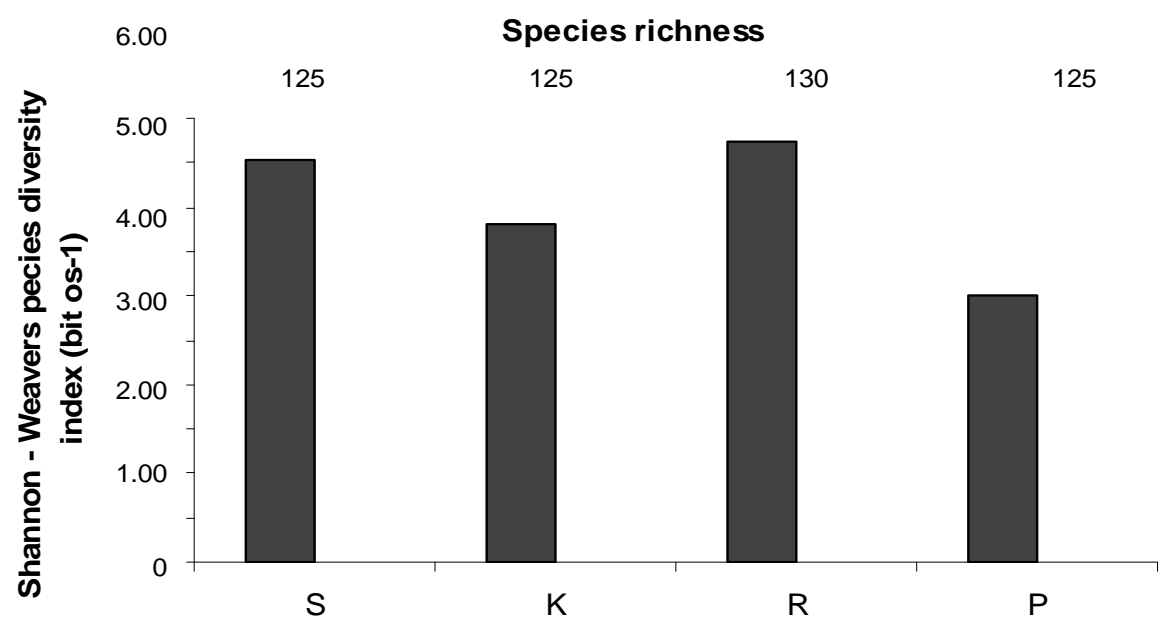

Figure 6. Species diversity Shannon-Weaver's coefficients for periphyton assemblages ( $S-$ periphyton in separator pipes, $K$ - epilithon, $R$-epiphtyton) and phytoplankton ( $P$ - pelagial) in Lake Jeziorak Maty in the years 1997-2003 and 2005 

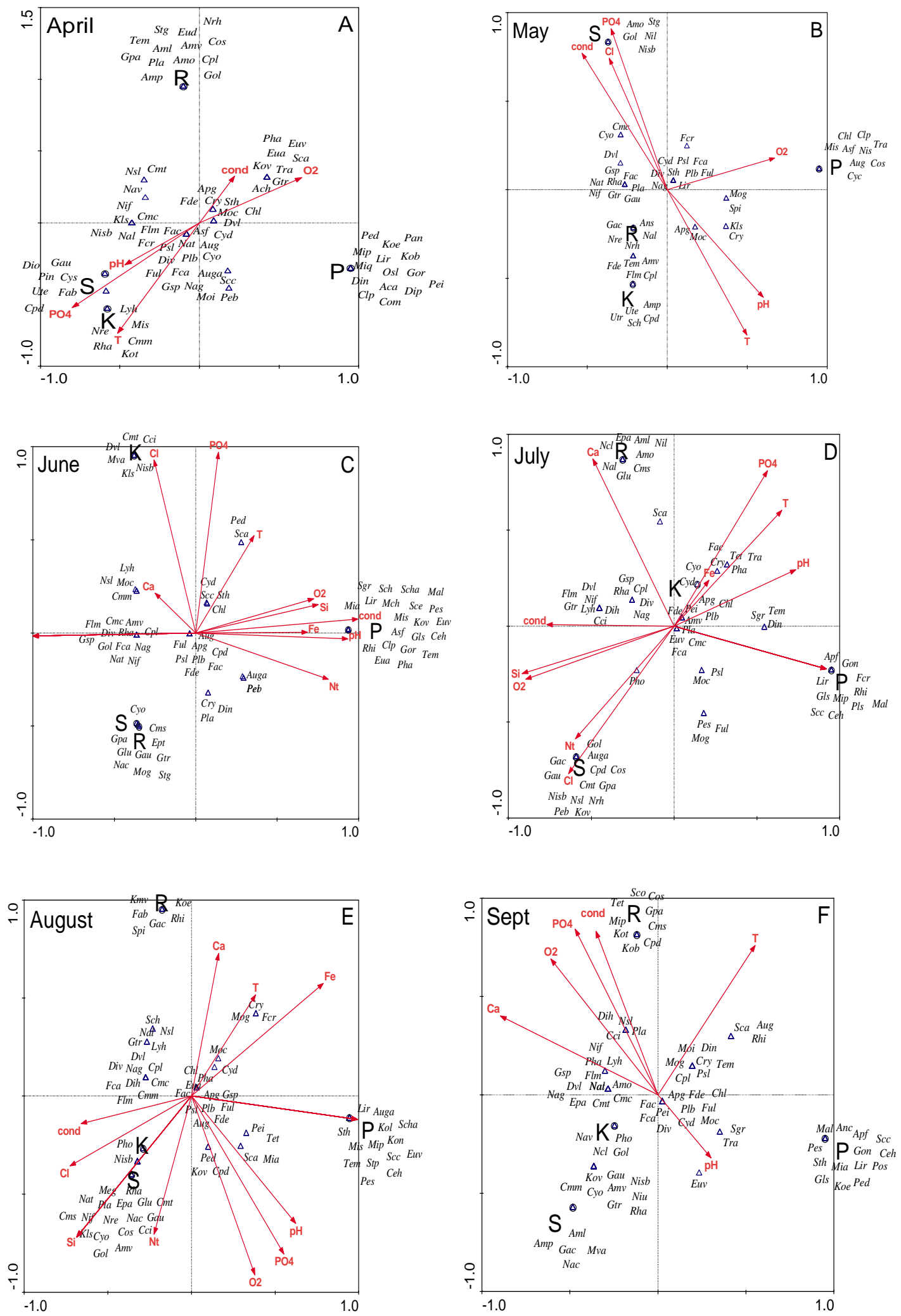

APPLIED ECOLOGY AND ENVIRONMENTAL RESEARCH 11(3): 323-342. http://www.ecology.uni-corvinus.hu • ISSN 15891623 (Print) • ISSN 17850037 (Online) 


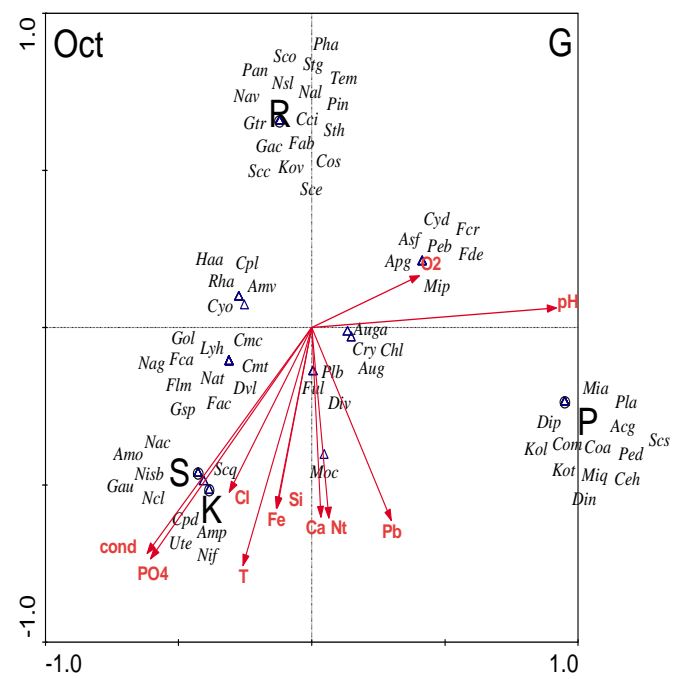

Figure 7. Tri-plots ordination diagram of Canonical Correspondence Analysis (CCA) showing the relationships between periphyton assemblages ( $S$ - periphyton in separator pipes, $K-$ epilithon, $R$-epiphtyton) and phytoplankton $(P-$ pelagial $)$ and physicochemical water parametres in the season from April to October (A-G) in Lake Jeziorak Maty (AcaActinastrum aciculare, Ach - Actinastrum hantzschii, Acg - Actinastrum gracilimum, AmlAmphora libyca, Amo - Amphora ovalis, Amp - Amphora pediculus, Amv-Amphora veneta, Anc - Anabaena crassa, Ans - Anabaena smithii, Apf - Aphanizomenon flos-aquae, Apg Aphanizomenon gracile, Asf - Asterinella formosa, Aug - Aulacoseira granulata, AugaAulacoseira granulata var. angustissima, Caa - Caloneis amphisbaena, Chl-Chlamydomonas spp., Ceh-Ceratium hirundinella, Clp-Closterium pronum, Cpd-Cocconeis pediculus, CplCocconeis placentula, Coa - Coleastrum astroideum, Com - Coleastrum microporum, Cos Cosmarium sp., Cry-Cryptomonas sp., Cyd-Cyclostephanos dubius, Cyc-Cyclotella comta, Cyo - Cyclotella ocellata, Cci-Cymbella cistula, Cmc-Cymbella compacta, Cmm-Cymbella microcephalla, Cms - Cymbella silesiaca, Cmt - Cymbella tumida, Dih - Diatoma hyemalis,

Div - Diatoma vulgaris, Dvl - Diatoma vulgaris var. linearis, Dip - Dictyosphaerium pulchellum, Din - Dinobryon sp., Dio - Diploneis ovalis, Epa - Epithema adnata, Ept Epithema turgida, Eud - Eudorina sp., Eua - Euglena acus, Euv - Euglena viridis, Fac-

Fragilaria acus, Fab - Fragilaria biceps, Fca - Fragilaria capucina, Fcr - Fragilaria crotonensis, Fde - Fragilaria delicatissima, Flm - Fragilaria leptostauron var. martyi, Ful -

Fragilaria ulna, Gor - Golenkinia radiata, Gls - Golenkiniopsis sp., Gac - Gomphonema acuminatum, Gau - Gomphonema augur, Glu - Gomphonema lungilatiforme, Gol-

Gomphonema olivaceum, Gpa - Gomphonema parvulum, Gtr-Gomphonema truncatum, Gsp Gomphonema spp., Gon - Gomphosphaeria naegeliana, Gyf - Gymnodinium fuscum, Haa Hantzschia amphioxys, Kls - Klebsormidium subtile, Kob - Koliella bernina, Koe - Koliella elongata, Kol - Koliella longiseta, Kon - Koliella nivalis, Kot - Koliella tenuis, Kov - Koliella variabilis, Kmv - Komvophoron schmidlei, Lir - Limnothrix redekei, Lyh-Lyngbya hieronymussii, Mal-Mallomonas sp., Mva-Melosira varians, Meg-Merismopedia glauca, Mip-Micratinium pusillum, Miq-Micratinium quadrisetum, Mia-Microcystis aeruginosa, Mch - Microcystis ichtyoblabe, Mis - Microcystis smithii, Moc-Monoraphidium concortum, Monoraphidium griffithii, Moi - Monoraphidium irregulare, Nac - Navicula capitata, Ncl Navicula clementis, Nag - Navicula gregaria, Nal - Navicula lanceolata, Nre - Navicula reinchardtii, Nrh - Navicula rhynchotella, Nsl - Navicula slesvicensis, Nat - Navicula tripunctata, Nav - Navicula viridula, Nif - Nitzschia frustulum, Nil - Nitzschia linearis, Nis Nitzschia sigmoidea, Nisb - Nitzschia sublinearis, Niu - Nitzschia uwellerstorffii, Osl Oscillatoria limosa, Pan - Pandorina sp., Peb-Pediastrum boryanum, Ped-Pediastrum duplex, Pei-Peridinium inconspicuum, Pes - Peridinium sp., Pha-Phacus sp., Pho- 
Phormidium sp., Pla - Planktothrix agardhii, Pin - Pinnularia sp., Pls - Planctoccoccus sphaerocystiformis, Plb - Planktolyngbya brevicellularis, Pos - Polyedropsis spinulosa, Psl -

Pseudanabaena limnetica, Rhi - Rhizosolenia sp., Rha - Rhoicosphenia abbreviata, ScaScenedesmus acuminatus, Scar - Scenedesmus armatus, Scc - Scenedesmus communis, Sce Scenedesmus ecornis, Sco - Scenedesmus opoliensis, Scq - Scendesmus quadrisspina, Scs Scenedesmus spinosus, Sch - Schroederia setigera, Spi - Spirogyra sp., Scha - Staurastrum chaetoceras, Sgr-Staurastrum gracile, Sth - Stephanodiscus hantzschii, Stp - Stichoccoccus pelagicus, Tem - Tetraedron minimum, Tet - Tetraplecton sp., Tra - Trachelomonas sp., UteUlothrix tenuissima, Utr - Ulothrix tenerrima)

Differences in species composition between the periphyton assemblages ( $\mathrm{S}$ periphyton in separator pipes, $\mathrm{K}$ - epilithon and $\mathrm{R}$ - epiphyton) and phytoplankton ( $\mathrm{P}$ pelagial) were also revealed in Lake Jeziorak Mały in the period from April to October (Fig. 7A-G). The data-set for statistical analysis was composed of 124 samples, 130 taxa, and 11 environmental variables. The first axis represented $41.7 \%, 49 \%, 58.4 \%$, $43.5 \%, 51.3 \%, 50.8 \%$ and $49.5 \%$ of the total species variation in succeeding months. The CCA showed that the species can be separated into the following four groups; (A) periphyton in separator pipes, (B) epilithon, (C) epiphyton and (D) phytoplankton. Periphyton in separator pipes and epilithon were the most similar assemblages in species composition. The diatom group included species from the genera Cymbella sp., Gomphonema sp., Navicula sp., and Rhoicosphenia abbreviata (Agardh) LangeBertalot, Melosira varians Agardh and Cocconeis pediculus Ehrenb. Moreover, species characteristic of the first assemblage were Nitzschia frustulum (Kützing) Grunow and of second assemblage, Diatoma vulgaris Bory. Chlorophytes were mainly represented by Ulothrix tenuissima Kützing and genus Stigeoclonium sp. The epiphyton included diatoms mainly from the genera Amphora sp., Cocconeis sp., Gomphonema sp., Navicula sp. and Pinnularia sp. Filamentous forms from genera Spirogyra sp. and Stigeoclonium sp., and planktonic forms from the genera Cosmarium sp., Koliella sp., Scenedesmus sp. and Tetraedron minimum species occurred in the chlorophytes. The most distinguished assemblages were phytoplankton, mainly including planktonic cyanobacteria and chlorophytes, where the cyanobacteria group included such species as Limnothrix redekei (Van Goor) Meffert, Planktothrix agardhii (Gom.) Anagn. \& Kom. and species from the genera Microcystis sp.; while the chlorophytes were represented by species from the genera Chlamydomonas sp., Scenedesmus sp., Staurastrum sp. and Pediastrum duplex Meyen and Tetraedron minimum (A.Braun) Hansg. Diatoms such as Aulacoseira granulata (Ehrenb.) Simonsen, Asterionella formosa Hassall, genus Rhizosolenia sp., dinoflagellates including Ceratium hirundinella (O. F. Müll.) Bergh. and chrysophytes and euglenines were also recorded.

\section{Relationships between species characteristic of periphyton and phytoplankton and physico-chemical water parameters}

The CCA analysis conducted on periphyton and phytoplankton showed significant relationships between species characteristic of these assemblages and the physical and chemical water parameters in the period from April to October. Meanwhile, periphyton in the separator pipes correlated with conductivity in May, June and October, with orthophosphate in spring (April), silicon in late summer (August), and chloride concentrations in May, July and August (Fig. 7A, D, E). Statistical analysis revealed 
that correlations between some of the species' abundance and these water parameters were statistically significant (Table 5).

Table 5. Environmental requirements of species characteristic of periphyton assemblages ( $S$ - periphyton in separator pipes, $K$ - epilithon, $R$ - epiphtyton) and phytoplankton ( $P$ pelagial) based on Spearman's correlation coefficients $(p<0.05)$ in Lake Jeziorak Maty in the years 1997-2003 and 2005

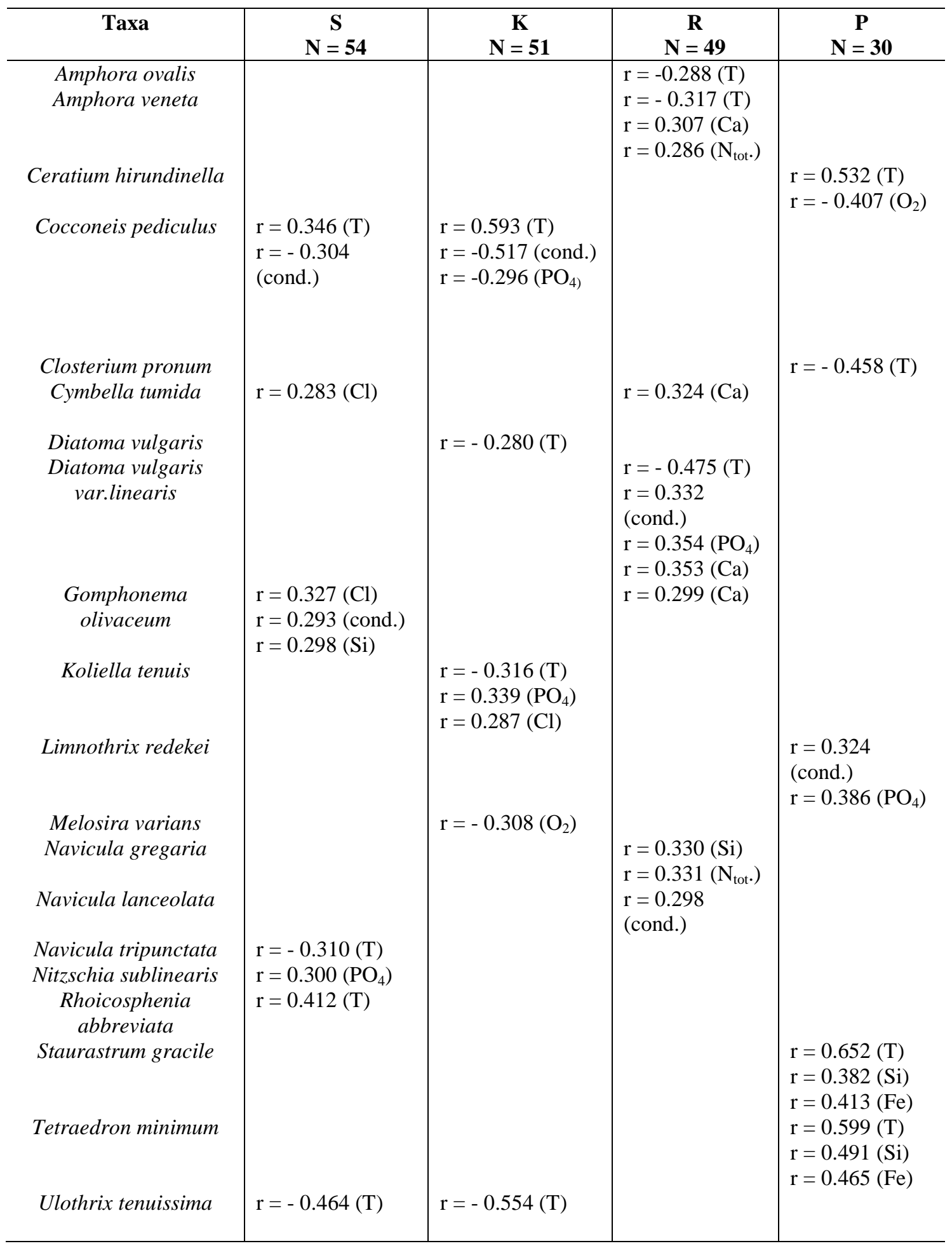


The following correlations were recorded; (1) Gomphonema olivaceum - a positive correlation with conductivity, $\mathrm{Si}$ and $\mathrm{Cl}(\mathrm{r}=0.293, \mathrm{r}=0.298$ and $\mathrm{r}=0.327, \mathrm{p}<0.05$, respectively); (2) Nitzschia sublinearis with $\mathrm{PO}_{4}(\mathrm{r}=0.300, \mathrm{p}<0.05)$ and (3) Cymbella tumida with $\mathrm{Cl}(\mathrm{r}=0.283, \mathrm{p}<0.05)$. In this study, epilithon correlated with water temperature and orthophosphates in spring and autumn (April, October), and with chlorides in summer and autumn (Fig. 7A, G). In these assemblages, Koliella tenuis positively correlated with $\mathrm{PO}_{4}$ and $\mathrm{Cl}(\mathrm{r}=0.339$ and $\mathrm{r}=0.287, \mathrm{p}<0.05$, respectively); and Diatoma vulgaris had a negative correlation with water temperature $(\mathrm{r}=-0.280, \mathrm{p}<$ $0.05)$ and Cocconeis pediculus with $\mathrm{PO}_{4}(\mathrm{r}=-0.296, \mathrm{p}<0.05$; Table 5). Correlations for epiphyton were recorded with calcium in summer (July) and with water temperature, conductivity and $\mathrm{PO}_{4}$ in the autumn month of September (Fig. 7 D, F). Here, the following correlations were recorded; (1) Amphora veneta with $\mathrm{Ca}(\mathrm{r}=0.307, \mathrm{p}<$ $0.05)$; (2) Gomphonema olivaceum with $\mathrm{Ca}(\mathrm{r}=0.299, \mathrm{p}<0.05)$; (3) Diatoma vulgaris var.linearis with $\mathrm{PO}_{4}$ and water temperature $(\mathrm{r}=0.354, \mathrm{r}=-0.317, \mathrm{p}<0.05$, respectively); (3) Navicula lanceolata with conductivity ( $\mathrm{r}=0.298, \mathrm{p}<0.05)$; and (4) Amphora veneta with water temperature $(\mathrm{r}=-0.475, \mathrm{p}<0.05)$ (Table 5). Phytoplankton also correlated with physico-chemical water parameters. Statistically significant relationships were recorded between characteristic phytoplankton species and electrolytic conductivity, $\mathrm{pH}$, oxygen content, iron, total nitrogen and silicon in the summer month of June (Fig. 7C). This assemblage included; cyanobacterium Limnothrix redekei correlated with conductivity $(\mathrm{r}=0.324, \mathrm{p}<0.05)$; chlorophytes Staurastrum gracile and Tetraedron minimum with $\mathrm{Fe}$ and $\mathrm{Si}(\mathrm{r}=0.413$ and $\mathrm{r}=0.382$, $\mathrm{p}<0.05$, respectively), and the dinoflagellate Ceratium hirundinella with $\mathrm{O}_{2}(\mathrm{r}=-0.407$, $\mathrm{p}<0.05)$ (Table 5).

\section{Discussion}

In descending order of occurrence, periphyte assemblages in eutrophic lakes comprise a large proportion of diatoms with less filamentous chlorophytes and then cyanobacteria, while the phytoplankton is often dominated by cyanobacteria. In Lake Jeziorak Mały in 1978, the dominance of cyanobacteria was more than $90 \%$ of the total phytoplankton biomass in the summer season (Spodniewska, 1986). During 1995-1996, before the implementation of protective-restorative work in the surface layer of the pelagial, the mean proportion of cyanobacteria was almost $93 \%$ of the total phytoplankton abundance, with 6\% diatoms and 12\% dinoflagellates (Zębek, 2009a). Some authors also recorded the dominance of cyanobacteria in similar strongly eutrophic lakes (Meffert, 1989; Nixdorf et al., 2003; Kangro et al., 2005). In Lake Jeziorak Mały in 1997-2003 and 2005, following the installation of separators and accumulation stones in the littoral zone, phytoplankton in the pelagial was still dominated by cyanobacteria, but at the lower level of $72 \%$, with $32 \%$ diatoms and $15 \%$ dinoflagellates (Zębek, 2012). Meanwhile, the periphytic assemblages (S - periphyton in separator pipes, $\mathrm{K}$ - epilithon, and $\mathrm{R}$ - epiphyton) were dominated by diatoms in terms of both abundance and biomass, with a maximum of over $90 \%$ for epilithon and $60 \%$ for periphyton in the separator pipes, respectively. Moreover, in the case of biomass, a significant presence of chlorophytes with a maximum of $42 \%$ for epilithon was observed (Zębek, 2012). This predominance of diatoms was comparable with others studies which examined eutrophic lakes' natural (Kuczyńska-Kippen et al., 2004; Vogel et al., 2005) and artificial substrata (Hansson, 1990; Szlauer, 1996; Danilov and 
Ekuland, 2001). This suggests that, following the implementation of protectiverestorative work in Lake Jeziorak Mały, the structure of periphyton and phytoplankton was typical of eutrophic lakes. Additionally, the decrease in the proportion of cyanobacteria and the increase in diatoms and dinoflagellates' proportion of the total abundance of phytoplankton in the studied period suggest a change in the lake's trophy from polytrophic to eutrophic. Additionally, the inflow of storm water into urban lakes such as Lake Jeziorak Mały from catchment areas can change the water chemistry and the environmental conditions for periphyton and phytoplankton. Increased chemical parameter values have been recorded in these lakes, including conductivity, $\mathrm{Ca}, \mathrm{Si}, \mathrm{PO}_{4}$, nutrients and chlorides (Guzkowska and Gasse, 1990). In this study, the separators supported the most varied environmental conditions compared to other sites. These registered the lowest mean water temperature, the highest water electrolytic conductivity and the highest concentrations of $\mathrm{Si}, \mathrm{Ca}$ and $\mathrm{N}_{\text {tot }}$, nutrients and chlorides. This suggests the enormous influence of polluted storm water inflow from this catchment (Zębek, 2012), thus influencing periphyton and phytoplankton development. Herein, the highest mean abundance of periphyton assemblages was recorded for periphyton in the pipes and the lowest in epiphyton, while the highest mean biomass was registered for epilithon at the highest orthophosphate concentration (Table 2).

Further factors influencing both phytoplankton and periphyton structure include light, temperature, water nutrient concentration, nutrient re-suspension from sediments and water movement (Reynolds, 1984; Nöges et al., 1998; Poulickova et al., 2004; Raeder et al., 2010). Moreover, the following factors are extremely important for periphyton; the substratum type and texture utilized by the organisms for habitat colonization, pressure from invertebrate organisms and the allelopathy of macrophytes (Hansson, 1990; Azim et al., 2005; Pals et al., 2006; Zębek et al., 2012). Differences in the abundance and biomass of periphyton assemblages on differ substrates were recorded in Lake Jeziorak Mały in Spring, Summer and Autumn, and these were similar to results recorded by Asaduzzaman et al. (2010). This was also supported by statistically significant differences registered in summer and autumn. However, no significant differences were recorded for algal abundance in spring (Table 3, Figs. 2, 3, 4). Seasonal differentiation in the studied periphyton and phytoplankton assemblages was determined by variations in environmental conditions at these sites, and especially by altered nutrient concentrations in the following seasons (Table 4). However, no significant differences between the periphyton in separator pipes and epilithon in summer and autumn (Figs. 3, 4) were related to approximate orthophosphate levels recorded at these sites (Table 4).

Differences in species composition and species diversity of the studied periphyton and phytoplankton assemblages were also observed herein. The Euclidean diagram showed that the greatest species composition similarity was between the periphyton in separator pipes and epilithon (Fig. 5). This suggests that both the separator pipe and stone-accumulation substrata exerted influence on the structural formation processes in algal assemblages. However disparity between the periphyton in separator pipes and phytoplankton (Fig. 5) most likely occurred due to different environmental conditions for algal development at these sites. Meanwhile, the greatest species diversity was recorded for epiphyton and the smallest for phytoplankton (Fig. 6). According to Reynolds (1993), the species diversity of algae in lakes is stimulated by autochthonic inflows such as nutrient re-suspension from sediments, and also by allochthonic factors, exemplified by the inflow of storm water through separators from catchments, as 
occurred in Lake Jeziorak Mały. The lower species diversity of periphyton in the separator pipes may be related to the intense and continuous water flow through these devices and the simultaneous inflow of organic matter. Such conditions could limit colonization by large algal forms and favour the development of small diatomous forms, such as Navicula gregaria, which tolerate large amounts of organic matter (Zębek et al., 2012; Zębek, 2012). The periphyton assemblages in Lake Jeziorak Mały registered greater species diversity than phytoplankton which agrees with the results of Kuczyńska-Kippen et al. (2004). The smallest species diversity in phytoplankton may relate to the high dominance of Planktolyngbya brevicellularis Cronberg \& Komárek cyanobacterium (Zębek, 2006; Zębek, 2012).

Differences in species composition and in the environmental requirements of species characteristic of the studied phytoplankton and periphyton assemblages were observed in Lake Jeziorak Mały from April to October. The phytoplankton composition largely included planktonic cyanobacteria and chlorophytes, and also dinoflagellates (Fig. 7A$G)$. This algal composition is typical of shallow eutrophic lakes. Here, the development of assemblages is formed by complex factors related to the hierarchical importance of nutrients - water temperature - light, and water-mixing (Reynolds, 1984). In this study, phytoplankton species correlated with conductivity, $\mathrm{pH}, \mathrm{O}_{2}, \mathrm{Fe}, \mathrm{N}_{\text {tot }}$ and $\mathrm{Si}$ in summer (Fig. 7A,G). These species preferred nutrient-rich waters with a high ion concentration of $419 \mu \mathrm{S} \mathrm{cm}^{-1}$, low oxygen content at $7.12 \mathrm{mg} \mathrm{O}_{2} \mathrm{l}^{-1}$ and high iron and silicon

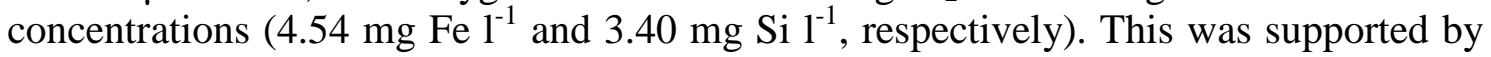
the positive correlation of Limnothrix redekei with conductivity, Staurastrum gracile and Tetraedron minimum with $\mathrm{Fe}$ and $\mathrm{Si}$; and the negative correlation of Ceratium hirundinella with $\mathrm{O}_{2}$ (Table 5). Meanwhile, periphyton assemblages were mainly formed by benthic diatoms and filamentous chlorophytes. The periphyton in separator pipes and epilithon were the most similar assemblages in species composition (Fig. 7), and this concurred with results of other authors who examined periphyton on artificial substrata in eutrophic lakes (Jöbgen et al., 2004; Asaduzzaman et al., 2010; Raeder et al., 2010). Here, the periphyton in separator pipes included small diatoms from the Navicula sp. and Nitzschia sp. genera which often occurred where there was a high level of water mixing (Reynolds, 1993). However, Diatoma vulgaris often occurred in epilithon and this is comparable with other studies (Kuczyńska-Kippen et al., 2004; Poulickova et al., 2004; Zębek, 2009b). The periphyton in the separator pipes correlated with conductivity, and with nutrients such as orthophosphates in spring, and silicon in summer (Fig. 7A, D, E). This was supported by the positive correlation between Gomphonema olivaceum and Nitzschia sublinearis and these water parameters (Table $5)$. These taxa preferred nutrient-rich waters, and they frequently occurred at high concentrations of these parameters; as in $665 \mu \mathrm{S} \mathrm{cm}^{-1}, 0.63 \mathrm{mg} \mathrm{PO}_{4} \mathrm{l}^{-1}$ and $2.72 \mathrm{mg} \mathrm{Si} \mathrm{l}^{-}$ 1 . Additionally, the high chloride concentrations in storm water inflow from catchments, especially following winter, influenced assemblage development. This is supported by the correlations between Gomphonema olivaceum and Cymbella tumida and chloride concentrations (Table 5). These species preferred a range from the moderate $35 \mathrm{mg} \mathrm{Cl} \mathrm{l}^{-}$ 1 to the high level of 52. This further suggests that the development of taxa characteristic of this assemblage was affected by changes in physico-chemical parameters. Herein, epilithon was correlated with orthophosphates, chlorides, and also water temperature, similar to the situation for periphyton in the pipes (Fig. 7A, G). The epilithic algae Koliella tenuis exhibited a positive correlation with $\mathrm{PO}_{4}$ and Diatoma vulgaris a negative correlation with water temperature (Table 5). These species 
preferred low water temperatures in spring and high orthophosphate concentrations in autumn, so that they were often encountered in $10.7^{\circ} \mathrm{C}$ and $0.84 \mathrm{mg} \mathrm{PO}_{4} \mathrm{l}^{-1}$. However, the positive correlation of Koliella tenuis with chlorides in Table 5 indicated that this water parameter may be considered a stimulatory factor encouraging its growth, especially in early summer. This species frequently occurred at a chloride level of 38 $\mathrm{mg} \mathrm{Cl}{ }^{-1}$. This also suggests that increased chlorides flowing through the separators to the lake can greatly influence epilithon development. Similar to studies by Danilov and Ekuland (2001); Pouličkova et al. (2004) and Laugaste and Reunanen (2005), the epiphyton here included diatoms mainly from the genera Amphora sp., Cocconeis sp., Gomphonema sp., Navicula sp. and Pinnularia sp., together with filamentous and planktonic forms of chlorophytes (Fig. 7A-G). The occurrence of planktonic chlorophytes in epiphyton indicated a similarity in species composition to phytoplankton. These epiphytic species preferred high $\mathrm{Ca}$ concentration in the summer, moderate conductivity and PO4 concentration and low water temperature in autumn (Fig. 7A,G). This was supported by the positive correlations between; Amphora veneta, Diatoma vulgaris var.linearis and Gomphonema olivaceum and $\mathrm{Ca} ; D$. vulgaris var.linearis and $\mathrm{PO}_{4}$; Navicula lanceolata and conductivity; and the negative correlation of Amphora veneta and D. vulgaris var.linearis with water temperature (Table 5). These

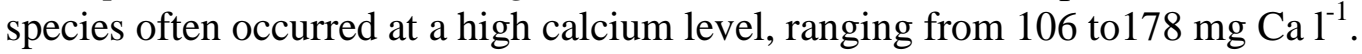

Periphyton can increase their abundance in the littoral zone of lakes and compete with phytoplankton for nutrients by potentially removing phosphorus from the water, and they can thus indirectly reduce phytoplankton biomass and cyanobacteria blooms (Hansson, 1990; Rodusky et al., 2001; Jöbgen et al., 2004). Rodusky et al. (2001) recorded maximum biomass of periphyton at a minimum phytoplankton biomass. This phenomenon may also have occurred in Lake Jeziorak Mały, where the periphyton assemblages registered higher biomass and was characterized by larger species diversity than recorded in phytoplankton (Table 2, Fig. 6). Moreover, the negative correlation in Table 5 supports Cocconeis pediculus epilithic diatoms contributing to the uptake of orthophosphates from the water. The reduction in phosphorus in the water has special implications in the development of phytoplankton dominated by cyanobacteria in fertile lakes such as Jeziorak Mały. In addition to the effects of separators, stone accumulations in the littoral zone can indirectly influence cyanobactera development. In the first case of separators, there is decreased water temperature and increased chlorides (Zębek, 2012), and the potential reduction in water phosphorus by epilithic diatoms and chlorophytes in the second case could limit cynaobacteria development.

\section{Conclusions}

The anthropogenically transformed littoral zone of Lake Jeziorak Mały by installation of separators and stone and gravel accumulation contributed to an increase in the number of habitats and species diversity of periphyton assemblages. These assemblages fulfill bio-filter functions through uptake of nutrients from the waters, and indirectly enhance phytoplankton growth dominated by cyanobacteria. The species characteristic of the studied periphyton and phytoplankton assemblages were divided into the following seven groups in terms of their environmental requirements:

(1) species preferring very fertile waters with very high orthophosphate concentration (Limnothrix redekei and Koliella tenuis) 
(2) species preferring high water temperature (Cocconeis pediculus, Rhoicosphenia abbreviata, Staurastrum gracile and Tetraedron minimum) and those occurring at low oxygen content (Ceratium hirundinella and Melosira varians)

(3) planktonic chlorophytes preferring high silicon and iron concentrations (Staurastrum gracile and Tetraedron minimum)

(4) species occurring in separator pipes preferring very fertile waters with very high chloride (Gomphonema olivaceum) and orthophosphate concentrations (Nitzschia sublinearis)

(5) species occurring in the separator pipes and in epilithon preferring less fertile waters with moderate conductivity, orthophosphate (Cocconeis pediculus) and chloride concentrations (Cymbella tumida, Koliella tenuis)

(6) diatoms and chlorophytes preferring low water temperature (Amphora ovalis, Amphora veneta, Closterium pronum, Diatoma vulgaris, Diatoma vulgaris var.linearis, Navicula tripunctata, Koliella tenuis and Ulothrix tenuissima), and

(7) epiphytic species preferring moderate fertile waters (Navicula lanceolata) with high calcium (Cymbella tumida, Diatoma vulgaris var.linearis, Gomphonema olivaceum) and nitrogen concentrations (Amphora veneta, Navicula gregaria).

The presence of these seven algal groups with different environmental preferences confirms the hypotheses contained in our study objectives, thus substantiating that their presence was infuenced by the installation of separators and stone accumulations in the littoral zone of this lake.

Acknowledgements. I wish to thank Prof. Lubomira Burchardt for many valuable suggestions on the previous version of the manuscript. I am grateful to native speaker Raymond H. Marshall for English reviewed.

\section{REFERENCES}

[1] Asaduzzaman, M., Rahman, M.M., Azim, M.E., Islam, M.A., Wahab, M.A., Verdegem, M.C.J., Verreth, J.A.J. (2010): Effects of C/N ratio and substrate addition on natural food communities in freshwater prawn monoculture ponds. - Aquaculture 306: 127-136.

[2] Azim, M.A, Verdegem, M.C.J., van Dam, A.A., Beveridge, C.M. (2005): Periphyton. Ecology, exploitation and management. - CABI Publishing, Oxfordshire, UK.

[3] Battarbee, R.W. (1979): Diatoms in lake sediments. - In: Berglund, B.E. (ed.) International Geological Correlation Programme Project 158, Paleohydrological Changes in the Temperate Zone in the Last 15,000 Years. Subproject B, Lake and Mire Environments. Dept. of Quaternary Geology, Lund, Sweden, 2, pp. 177-225.

[4] Bohr, R. (1973): Phytosociology of periphyton. - Pol. Arch. Hydrobiol. 20(1): 185-188.

[5] Bohr, R., Miotk, G. (1979): The primary production of periphytic algae in the south part of the Jeziorak Lake. - Acta Universitatis Nicolai Copernici 47(11): 13-17.

[6] Burchardt, L. (1998): Phenomenon of compensation in a shallow water ecosystem. - In: Radwan, W.S. (ed.) Freshwater ecotones. Structure - genera - functioning. UMCS Press, Lublin, Poland, pp. 273-278. 
[7] Danilov, R.A., Ekuland, N.G.A. (2001): Comparison of usefulness of three types of artificial substrata (glass, wood and plastic) when studying settlement pattern of periphyton in lakes of different trophic status. - J. Microbiol. Methods 45: 167-170.

[8] Dodds, W.K. (2003): The role of periphyton in phosphorus retention in shallow freshwater aquatic systems. - J. Phycol. 39: 840-849.

[9] Guzkowska, M.A.J., Gasse, F. (1990): Diatoms as indicators of water quality in some English Urban lake. - Freshwater Biol. 23: 233-250.

[10] Hansson, L.A. (1990): Quantifying the impact of periphytic algae on nutrient availability for phytoplankton. - Freshwater Biol. 24: 265-273.

[11] Jöbgen, A.M., Palm, A., Melkonian, M. (2004): Phosphorus removal from eutrophic lakes using periphyton on submerged artificial substrata. - Hydrobiologia 528: 123-142.

[12] Kangro, K., Laugaste, R., Nõges, P., Ott, I. (2005): Long-term changes and seasonal development of phytoplankton in a strongly stratified, hypertrophic lake. -Hydrobiologia 547: 91-103.

[13] Kuczyńska-Kippen, N., Messyasz, B., Nagengast, B. (2004): The structure of the periphytic communities of the Wielkowiejskie Lake. - Roczniki Akademii Rolniczej w Poznaniu 358(7): 175-191.

[14] Laugaste, R., Reunanen, M. (2005): The composition and density of epiphyton on some macrophyte species in the partly meromictic Lake Verevi. - Hydrobiologia 547: 137-150.

[15] Meffert, M.E. (1989): Planktic unsheathed filaments (Cyanophyceae) with polar and central gas vacuoles. II. Biology, population dynamics and biotopes of Limnothrix redekei (Van Goor) Meffert. - Arch. Hydrobiol. 116(3): 257-282.

[16] Müller, U. (2000): Periphytic primary production during spring. A sink of source of oxygen in the littoral zone? - Limnologica 30: 169-174.

[17] Nixdorf, B., Mischke, U., Rücker, J. (2003): Phytoplankton assemblages and steady state in deep and shallow eutrophic lake - an approach to differentiate the habitat properties of Oscillatoriales. - Hydrobiologia 502: 111-121.

[18] Nõges, P., Järvet, A., Tuvikene, L., Nõöges, T. (1998): The budgets of nitrogen and phosphorus in shallow eutrophic Lake Vörtjärv (Estonia). - Hydrobiologia 363: 219-227.

[19] Pals, A., Elst, D., Muylaert, K., van Assche, J. (2006): Substrate specificity of periphytic desmids in shallow softwater lakes in Belgium. - Hydrobiologia 568: 159-168.

[20] Pelechaty, M., Burchardt, L. (1998): The problems of bioindication in the ecotone zone of lakes. - In: Radwan, S. (ed.) Freshwater ecotones. Structure - genera - functioning. UMCS Press, Lublin, pp. 99-106.

[21] Pouličkova, A., Duchoslav, M., Dokulil, M. (2004): Littoral diatom assemblages as bioindicators of lake trophic status: A case study from perialpine lakes in Austria. - Eur. J. Phycol. 39: 143-152.

[22] PUH EKOL. (1995): Separators of oils and petrols (records).

[23] Radwan, S., Stępień, B., Bojar, W., Koproń, J. (1998): Physical and chemical factors of different habitats of littoral and pelagic zones of some Polesie Lubelskie lakes. - In: Radwan, S. (ed.) Freshwater ecotones. Structure - genera - functioning, UMCS Press, Lublin, pp. 161-175.

[24] Raeder, U., Ruzicka, J., Goos, C. (2010): Characterization of the light attenuation by periphyton in lakes of different trophic state. - Limnologica 40: 40-46.

[25] Reynolds, C.S. (1984): Phytoplankton periodicity: the interaction of form, function and environmental variability. - Freshwater Biol. 14: 111-142.

[26] Reynolds C.S. (1993): Scales of disturbance and their role in plankton ecology. Hydrobiologia 249: 157-171.

[27] Rier, S.T., Stevenson, R.J. (2006): Response of periphytic algae to gradients in nitrogen and phosphorus in streamside mesocoms. - Hydrobiologia 561: 131-147.

[28] Rodusky, A.J., Steinman, A.D., East, T.L., Sharfstein, B., Meeker, R.H. (2001): Phytoplankton nutrient limitation and other potential growth - controlling factors in Lake Okeechobee, U.S.A. - Hydrobiologia 448: 27-39. 
[29] Rott, E. (1981): Some results from phytoplankton counting intercalibrations. - Schweiz. Z. Hydrol. 43: 34-62.

[30] Shannon, C.E., Weaver, W. (1949): The mathematical theory of communication. Urbana.

[31] Spodniewska, I. (1986): Planktonic blue-green algae of lakes in north-eastern Poland. Ekologia Polska 34( 2): 151-183.

[32] Szlauer, L. (1996): Determination method of the volume of periphyton components. Polskie Archiw. Hydrobiol. 43(1): 3-8.

[33] Vogel, A., Beier, T., Braun, J., Raeder, U. (2005): Does the process of drying submerged macrophytes affect community structure and composition of epiphytic diatoms? Hydrobiologia 541: 237-240.

[34] Zębek, E. (2006): Quantitative changes of Planktolyngbya brevicellularis, Limnothrix redekei and Aphanizomenon gracile in the annual cycle vs. physicochemical water parameters in the urban Lake Jeziorak Mały. - Oceanol. Hydrobiol. St. 35(1): 69-84.

[35] Zębek, E. (2009a): Seasonal changes in net phytoplankton in two lakes with differing morphometry and trophic status (northeast Poland). - Archives of Polish Fisheries 17: 267-278.

[36] Zębek, E. (2009b): Seasonal changes in the planktonic and periphytic diatoms with relation to physicochemical water parameters in the littoral zone of the Lake Jeziorak Mały. - Teka Komisji Ochrony i Kształtowania Środowiska Przyrodniczego 6: 432-439.

[37] Zębek, E., Bonar, A., Szymańska, U. (2012): Periphytic diatom communities in the littoral zone of the urban lake Jeziorak Mały (Masurian Lake District, Poland). - Ekológia (Bratislava) 31(1): 105-123.

[38] Zębek, E. (2012): Effect of separators on development of cyanobacteria (phytoplankton) and periphyton in a shallow urban lake (Lake Jeziorak Mały, Poland) (in printed). 